\title{
EVALUASI PELAKSANAAN E-PURCHASING OBAT PADA DINAS KESEHATAN KABUPATEN/KOTA DI JAWA TENGAH TAHUN 2015
}

\author{
EVALUATION OF MEDICINES E-PURCHASING AT DISTRICT HEALTH OFFICES / \\ MUNICIPALITIES IN CENTRAL JAVA PROVINCE 2015
}

\author{
Kusmini $^{1)}$, Satibi ${ }^{2)}$, Sri Suryawati ${ }^{3)}$ \\ 1) Fakultas Farmasi, Universitas Gadjah Mada, Yogyakarta \\ 2) Fakultas Farmasi, Universitas Gadjah Mada, Yogyakarta \\ 3) Fakultas Kedokteran, Universitas Gadjah Mada, Yogyakarta
}

\begin{abstract}
ABSTRAK
Metode pengadaan obat secara e-purchasing berdasarkan e-catalogue merupakan sistem pengadaan obat yang relatif baru di Indonesia. E-purchasing obat bertujuan untuk meningkatkan transparansi, efektifitas dan efisiensi proses pengadaan obat di era Jaminan Kesehatan Nasional (JKN). Dampak kendala e-purchasing obat banyak dirasakan satuan kerja di bidang kesehatan, termasuk di Jawa Tengah. Penting untuk mengetahui hambatan yang terjadi pada pelaksanaan e-purchasingobat dan dampaknya. Tujuan dari penelitian ini untuk mengetahui permasalahan yang menjadi hambatan pada pelaksaaan e-purchasing obat dan dampaknya terhadap ketersediaan obat dan efisiensi biaya. Penelitian ini merupakan penelitian observasional studi kasus yang bersifat deskriptif analitis. Data yang digunakan berupa data retrospektif dan prospektif. Data retrospektif tahun 2015 meliputi data rencana e-purchasing, realisasi e-purchasing, hambatan e-purchasing, realisasi none-purchasing dan ketersediaan obat. Data prospektif meliputi pendalaman terkait hambatan pelaksanaan e-purchasing obat. Penelitian dilakukan pada 35 dinas kesehatan kabupaten/kota (DKK) di Jawa Tengah.Data kuantitatif diolah dan disajikan dalam bentuk tabel dan data kualitatif dianalisis dengan content analysis. Hasil penelitian menunjukkan bahwa 45,3\% obat indikator diadakan melalui mekanismee-purchasingoleh 97,3\% DKK.Realisasi obat yang tidak sesuai rencana sebesar 23,9\%, yang menunjukkan adanya hambatan pelaksanaan e-purchasing. Hambatan terbesar adalah ketidakmampuan suplai oleh industri farmasi (IF) penyedia. Hambatan berdampak pada pengurangan ketersediaan obat dan efisiensi biaya obat. Pelaksanaan e-purchasingyang berjalan lancar akan menyumbangkan potensi penghematan biaya obat sebesar 19,1\%. Kesimpulan, terdapat hambatan pelaksanaan e-purchasing obat. Hambatan terbesar adalah ketidakmampuan suplai oleh IF. Hambatan berdampak pada pengurangan ketersediaan obat dan efisiensi biaya obat. Terjadi potensi penghematan biaya obat pada pelaksanaan e-purchasing yang berjalan lancar.
\end{abstract}

Kata kunci: e-purchasing, hambatan, ketersediaan obat, efisiensi biaya obat

\section{ABSTRACT}

Procurement of medicine by e-purchasing based on e-catalogue is a new medicines procurement system in Indonesia. Medicines epurchasing is aimed to improving transparency, effectiveness and efficiency of medicines procurement process in the era of National Health Insurance (UHC). Impact of e-purchasing impediments perceived medicinal work units in the field of health including in Central Java. It is important to identify the impediments that occur in the implementation of the medicines e-purchasing and its effects. The purpose of this study was to determine the impediments on the implementing medicines e-purchasing and their impact on medicines availability and cost efficiency. This study is a non-experimental observational case studies presented by descriptive analysis. Data used in the form of data retrospectively and prospectively. The retrospective data on 2015 included is e-purchasing plan, e-purchasing realization, impediments e-purchasing implementation,non e-purchasing realization and medicinesavailability data. Deepening related impediments e-purchasing implementation by depth interviews. The study was conducted at 35 district health offices/municipalities in Central Java. Content analysis was applied to determine the impediments on the implementation of e-purchasing. Quantitative data is processed and presented in tables informing mismatch of procurement, medicinesavailability and potential medicines cost savings. The results showed that $45.3 \%$ of medicines indicators was procured by e-purchasing by $97,3 \%$ district health offices/municipalities. The mismatch between medicines e-purchasing realization andthe plan amounted to $23.9 \%$. The mis match shows the impediments of e-purchasing implementation. Impediments of e-purchasing reduced the medicines availability and the medicines cost efficiency. Implementation of e-purchasing leads to potential savings in medicines costs by $19,1 \%$. Conclusion. There are impedimens to the implementation of medicines e-purchasing. The biggest impediments was the inability of supply by the pharmaceutical industry provider. Impediments impact on reducing the medicines availability and medicines cost efficiency. Implementation of e-purchasing leads to potential savings in medicines costs.

Keywords: e-purchasing, impediments, medicines availability, medicines cost efficiency

\section{Korespondensi}

Kusmini

MMF, Universitas Gadjah Mada

Email : miminapt.ugm98@gmail.com

\section{PENDAHULUAN}

Obat merupakan komponen penting yang ketersediaannya berpengaruh dalam keberhasilan penyelenggaraan upaya kesehatan. Sejak era otonomi daerah kewajiban penyediaan dan pengelolaan obat publik untuk wilayah kabupaten/kota merupakan kewajiban 
pemerintah daerah. Dinas kesehatan kabupaten/kota (DKK) merupakan satuan kerja pemerintah daerah di bidang kesehatan yang salah satu tugas dan kewenangannya adalah menyediakan dan mengelola obat publik untuk wilayah kabupaten/kota. Pengadaan obat merupakan salah satu elemen dalam siklus manajemen obat yang bertujuan untuk menjamin ketersediaan obat dengan kualitas standar, dalam jumlah yang tepat, dan dengan biaya seminimal mungkin. Penelitian mengenai pengadaan obat telah banyak diteliti (Winarni, 2006; Iswahyudi, 2007; Puspita, 2009; Pratiwi, 2011).Pengadaan obat oleh dinas kesehatan berpedoman pada peraturan pengadaan barang/jasa pemerintah yang diatur dalam Peraturan Presiden Nomor 54 Tahun 2010 dan aturan turunannya. Pengadaan obatyang tersedia dalam daftar katalog elektronik ( $e$ catalogue) metode pembelian wajib secara $e$ purchasing. Jika obat yang dibutuhkan tidak terdapat dalam e-catalogue obat, proses pengadaan dapat mengikuti metode lainnya sesuai pedoman pengadaan barang/jasa pemerintah (Kementerian Kesehatan RI, 2014).

$$
\text { E-purchasing merupakan salah }
$$

satu metode pengadaan berbasis elektronik (e-procurement). E-procurement merupakan pemanfaatan sistem teknologi informasi dalam otomatisasi proses pengadaan (Bottani dan Rizzi, 2005). E-procurement telah dilaksanakan di berbagai negara, seperti yang telah diteliti oleh Gunasekaran et al. (2008) di Hongkong, Teo et al (2009) di Singapura, Eei et al (2012) di Malaysia. Implementasi sistem e-procurement pada sektor kesehatan telah diteliti oleh Ketikidis et al (2010).

Sistem e-procurement obat berdasarkan ecatalogue merupakan sistem pengadaan obat yang baru di Indonesia yang bertujuan untuk meningkatkan transparansi, efektifitas dan efisiensi proses pengadaan obat. Menjelang empat tahun berjalannya e-purchasing obat di Indonesia, berbagai penelitian sudah dilakukan untuk mengetahui implementasinya. Sutriatmoko et al (2015) melakukan analisis penerapan e-purchasing berdasarkan e-catalogue yang bertujuan mempelajari variabel yang berpengaruh terhadap kinerja e-purchasing obat dan pengaruh kinerja terhadap efisiensi pengadaan obat di dinas kesehatan. Ningsih et al (2015) meneliti tentang hubungan penerapan e-katalog terhadap efisiensi pengadaan dan ketersediaan obat secara kualitatif di rumah sakit. Penelitian yang bertujuan mengidentifikasi hambatan pelaksanaanepurchasing obat dan dampaknya terhadap ketersediaan dan efisiensi biaya obat belum pernah dilakukan. Penelitian sebelumnya yang dilakukan oleh Dwiaji et al (2016) melakukan evaluasi pemesanan obat secara elektronik dibandingkan dengan rencana kebutuhan obat.

Pada penelitian ini dilakukan evaluasi pelaksanaan e-purchasing obat di dinas kesehatan kabupaten/kota di Provinsi Jawa Tengah untuk mengidentifikasi hambatan pelaksanaannya dan dampaknya terhadap ketersediaan dan efisiensi biaya obat. Provinsi Jawa Tengah terbagi menjadi 29 kabupaten dan 6 kota. Luas wilayah sekitar 25\% dari luas pulau jawa. Jumlah penduduk sekitar $13 \%$ persen dari total penduduk Indonesia dan merupakan provinsi ketiga di Indonesia dengan jumlah penduduk terbanyak. Jawa Tengah adalah salah satu barometer nasional. Penting untuk mengetahui pelaksanaan e-purchasing obat di DKK di Provinsi Jawa Tengah. Hasil penelitian dapat menjadi bahan pertimbangan pemegang kebijakan untuk perbaikan dan peningkatan sistem pengadaan obat.

E-purchasing obat merupakan tata cara pembelian obat sesudah sistem e-catalogue obat terbangun (Kementerian Kesehatan RI, 2014). Ecatalogue obat adalah sistem informasi elektronik yang memuat daftar, jenis, spesifikasi teknis, dan harga obat dari berbagai penyedia obat.Produk IF penyedia dan informasi harga yangditampilkan melalui katalog elektronik bisa diakses oleh pembelimelalui web. Pada proses pembelian keputusan menjadi lebih mudah (Ketikidis et al., 2010).

Sebagai sistem pengadaan obat yang baru, terdapat hambatan dalam pelaksanaan $e$ purchasing obat. Hambatan dalam penerapan $e$ purchasing obat berdasarkan e-catalogue antara lain (1) Obat tidak ada di e-catalogue, Pemesanan tidak direspon oleh IF penyedia sementara kebutuhan mendesak dan tidak 
dapat ditunda, (3) IF penyedia telah menyetujui pemesanan tapi baru tersedia beberapa bulan kemudian atau waktu pengiriman terlalu lama, (4) Penolakan pemesanan oleh IF penyedia karena stok tidak tersedia, (5) IF penyedia dikenakan sanksi administratif berupa penghentian sementara kegiatan, (6) Kendala operasional e-purchasing, (7) Faskes swasta tidak bisa melakukan pengadaan secara e-purchasing, (8) Pembayaran yang tertunda, (9) Distributor tidak memenuhi kesepakatan waktu pengiriman, tanggal kedaluwarsa produk dan return barang, (10) Distributor meminta biaya pengiriman, (11) Tidak ada tenaga kefarmasian dalam pemesanan obat oleh dinas kesehatan atau puskesmas (Kementerian Kesehatan RI, 2016).

Kendala suplai IF penyedia menyebabkan realisasi e-purchasing obat tidak sesuai dengan rencana. Dampak yang paling sering terjadi pada fasilitas pelayanan akibat hambatan pada pelaksanaan e-purchasing obatadalah terjadinya kekosongan obat untuk pelayanan, ketidaktersediaan obat untuk pelayanan dan potensi inefisiensi anggaran penyediaan obat akibat tidak terpenuhinya pengadaan obat secara e-purchasing. Akibat terjadi kekosongan dan kelangkaan obat, hampir setiap pasien, termasuk pasien miskin, mengeluarkan biaya untuk berobat.

Penelitian ini bertujuan untuk mengetahui kesesuaian antara rencana dengan realisasi e-purchasing obat, mengidentifikasi permasalahan yang menghambat pelaksanaan $e$ purchasing obat, mengetahui dampak hambatan pada ketersediaan dan efisiensi biaya obat dan mengetahui potensi penghematan pengadaan obat secara e-purchasing dibanding pengadaan secara non e-purchasing pada tahun 2015. Hasil penelitian diharapkan dapat memberi masukan untuk perbaikan implementasi $e$-purchasing obat di Indonesia.

\section{METODE}

Penelitian ini merupakan penelitian non eksperimental observasional dengan rancangan studi kasus untuk mendeskripsikan secara analitis gambaran hambatan yang terjadi pada pelaksanaan pengadaan obat secara $e^{-}$ purchasingdan dampaknya terhadap ketersediaan obat dan efisiensi biaya obat. Unit penelitian adalah semua DKK di wilayah Jawa Tengah. Waktu penelitian tahun 2016 dengan mengambil data pelaksanaan e-purchasingobat tahun 2015. Unit analisis penelitian adalah proses e-purchasingobat di semua DKK di Jawa Tengah. Untuk memperoleh data yang tepat tentang proses e-purchasing obat di DKK, responden ditentukan secara purposive sampling yaitu orang yang dianggap paling mengetahui dan berkepentingan serta bertanggung jawab pada proses pengadaan dan atau pengeloaan obat di DKK. Peneliti mengajukan izin penelitian ke wilayah penelitian, instansi penelitian, kesediaan responden (informed consent) untuk mengikuti penelitian dan ethical clearance.

Data yang digunakan untuk mengetahui hambatan pelaksanaan e-purchasing obat di DKK adalah data rencana e-purchasing, data realisasi e-purchasing, kesesuaian antara rencana dan realisasi serta penyebab ketidak sesuaian. Informasi terkait dengan hambatan pelaksanaan e-purchasing lebih lanjut digali dari hasil wawancara mendalam dengan responden.

Data yang digunakan untuk mengetahui dampak hambatan pelaksanaan e-purchasing obat pada ketersediaan obat adalah data mutasi obat tahun 2015. Dampak pada efisiensi biaya diperoleh dari informasi dari responden terkait dengan tindak lanjut pengadaan obat secara non e-purchasing akibat tidak atau kurang tersuplainya obat yang diadakan secara $e$ purchasing.

Data yang dikumpulkan diklasifikasi menjadi dua yaitu data kuantitatif dan data kualitatif. Data kuantitatif diolah dan disajikan dalam bentuk tabel yang menginformasikan ketidaksesuaian pengadaan, ketersediaan obat dan potensi penghematan biaya obat. Dilakukan conten analysis terhadap data kualitatif untuk menganalisis hambatan pelaksanaan $e$ purchasing.

\section{HASIL DAN PEMBAHASAN}

Semua unit penelitian mengembalikan format isian data meskipun ada beberapa yang memerlukan klarifikasi ulang, terpenuhinya 
Tabel I. Pelaksanaan E-Purchasing Obat di DKK di Jawa Tengah Tahun 2015 dan Tindak Lanjutnya

\begin{tabular}{lcccccccc}
\hline \multirow{2}{*}{ Kegiatan } & \multicolumn{2}{c}{ DKK } & \multicolumn{2}{c}{ Jenis obat } & Jumlah Obat & \multicolumn{2}{c}{ Nilai Nominal } \\
\cline { 2 - 9 } & Jumlah & Persentase & Jumlah & Persentase & Jumlah & Persentase & Jumlah & Presentase \\
\hline DKK & 35 & & 19 & & 665 & & & \\
Pelaksanaan E-Purchasing & 34 & $97,1 \%$ & 19 & $100,0 \%$ & 301 & $45,3 \%$ & 16.497 .777 .295 & \\
Realisasi E-Purchasing sesuai rencana & 5 & $14,7 \%$ & 5 & $26,3 \%$ & 229 & $76,1 \%$ & 11.168 .300 .945 & $67,7 \%$ \\
Realisasi E-Purchasing tidak sesuai rencana & 29 & $85,3 \%$ & 14 & $73,7 \%$ & 72 & $23,9 \%$ & 5.329 .476 .350 & $32,3 \%$ \\
Tindak lanjut Realisasi E-Purchasing tidak sesuai rencana & 14 & $48,3 \%$ & 9 & $64,3 \%$ & 25 & $34,7 \%$ & 2.668 .850 .700 & $50,1 \%$ \\
$\begin{array}{l}\text { Tidak ada Tindak lanjut Realisasi E-Purchasing tidak } \\
\text { sesuai rencana }\end{array}$ & 15 & $51,7 \%$ & 6 & $42,9 \%$ & 47 & $65,3 \%$ & 2.660 .625 .650 & $49,9 \%$ \\
\hline
\end{tabular}

Tabel II. Kodifikasi Jenis Hambatan Pelaksanaan E-Purchasing Obat

\begin{tabular}{|c|c|c|c|c|}
\hline Jenis Hambatan & Internal & Ekstemal & Koding & Sumber \\
\hline Obat tidak ada di $E$-Catalogue & & $\mathrm{v}$ & E1 & \multirow{11}{*}{$\begin{array}{l}\text { Kementerian } \\
\text { Kesehatan RI } \\
\quad(2016)\end{array}$} \\
\hline $\begin{array}{l}\text { Pemesanan tidak direspons oleh IF peryedia } \\
\text { sementara kebutuhan mendesak dan tidak } \\
\text { dapat ditunda; }\end{array}$ & & $\mathrm{v}$ & E2 & \\
\hline $\begin{array}{l}\text { IF peryedia telah menyetujui pemesanan tapi } \\
\text { baru tersedia beberapa bulan kemudian atau } \\
\text { waktu pengiriman terlahu lama }\end{array}$ & & $\mathbf{v}$ & E3 & \\
\hline $\begin{array}{l}\text { Penolakan pemesanan oleh IF penyedia karena } \\
\text { stok tidak tersedia }\end{array}$ & & $\mathrm{v}$ & E4 & \\
\hline $\begin{array}{l}\text { IF penyedia dikenakan sanksi administratif } \\
\text { berupa penghentian sementara kegiatan; }\end{array}$ & & $\mathbf{v}$ & E5 & \\
\hline Kendala operasional E-Purchasing; & $\mathrm{v}$ & & I1 & \\
\hline Pembayaran yang tertunda; & $\mathrm{v}$ & $\mathrm{v}$ & IE1 & \\
\hline $\begin{array}{l}\text { Distributor tidak memenuhi kesepakatan waktu } \\
\text { pengiriman, tanggal kedaluwarsa produk dan } \\
\text { return barang; }\end{array}$ & & $\mathrm{v}$ & E6 & \\
\hline Distributor meminta biaya pengiriman; & & $\mathrm{v}$ & E7 & \\
\hline $\begin{array}{l}\text { Tidak ada tenaga kefarmasian dalam } \\
\text { pemesanan obat }\end{array}$ & $\mathbf{v}$ & & $\mathrm{I} 2$ & \\
\hline Terlambat mengunggah surat pesanan & $\mathrm{v}$ & & I3 & \\
\hline $\begin{array}{l}\text { IF penyedia telah menyetujui pemesanan tetapi } \\
\text { obat hanya terkirim sebagian }\end{array}$ & & $\mathbf{v}$ & E8 & \multirow{4}{*}{$\begin{array}{l}\text { Hasil } \\
\text { Pengembangan } \\
\text { di Lapangan }\end{array}$} \\
\hline $\begin{array}{l}\text { IF penyedia menyetujui sebagian pesanan } \\
\text { karena stok terbatas atau kendala kapasitas } \\
\text { produksi }\end{array}$ & & $\mathrm{v}$ & E9 & \\
\hline $\begin{array}{l}\text { IF penyedia telah menyetujui pemesanan tetapi } \\
\text { obat tidak dikirim }\end{array}$ & & $\mathrm{v}$ & E10 & \\
\hline $\begin{array}{l}\text { Distributor tidak segera memberikan Surat } \\
\text { Pesanan kepada IF penyedia, sehingga sampai } \\
\text { akhir masa kontrak, distributor haryya bisa } \\
\text { memberikan barang seadanya }\end{array}$ & & $\mathrm{v}$ & E11 & \\
\hline
\end{tabular}

data untuk penelitian ini menunjukkan bahwa 35 unit penelitian mempunyai sistem pencatatan dan pelaporan obat yang baik. Jarak yang jauh tidak menghambat pengambilan data penelitian. Responden mempunyai kemauan untuk bekerjasama dalam menyediakan data yang diperlukan. Sebagian besar responden perempuan $(57,8 \%)$. Jabatan sebagai kepala instalasi farmasi kabupaten/kota (IFK) (48,9\%) dan mayoritas bekerja selama $6-10$ tahun $(40,0 \%)$ dengan tingkat pendidikan mayoritas adalah S1-Apoteker (68,9\%). 
Tabel III. Hasil Evaluasi Hambatan Pelaksanaan E-Purchasing Obat

\begin{tabular}{|c|c|c|c|c|c|c|c|c|}
\hline \multirow{2}{*}{ Nama Obat } & \multicolumn{8}{|c|}{ Jumlah Hambatan E-Purchasing di DKK } \\
\hline & $\mathbf{E 2}$ & $\mathbf{E 4}$ & E6 & E8 & E9 & E10 & E11 & Total \\
\hline Amoxicillin $500 \mathrm{mg}$ tab & & 1 & & 6 & 12 & 2 & & 21 \\
\hline Glibenklamid & & 3 & & 2 & 10 & & & 15 \\
\hline Furosemid tablet $40 \mathrm{mg}$ & & & & & 13 & & & 13 \\
\hline Deksametason tab & 1 & 4 & & 1 & & 1 & & 7 \\
\hline Epinefrin (Adrenalin) injeksi $0,1 \%$ & 1 & 1 & 1 & & & & & 3 \\
\hline Oksitosin injeksi & & 2 & & & & 1 & & 3 \\
\hline Amoxicillin syrup $125 \mathrm{mg} / 5 \mathrm{ml}$ & & 1 & & & & & 1 & 2 \\
\hline Fitomenadion (Vitamin $\mathrm{K}$ ) injeksi & 1 & & & & 1 & & & 2 \\
\hline Diazepam injeksi $5 \mathrm{mg} / \mathrm{mL}$ & & & & & & 1 & & $\mathbf{1}$ \\
\hline Garam oralit & & 1 & & & & & & $\mathbf{1}$ \\
\hline Kaptopril tab $12,5 \mathrm{mg}$ & & & & 1 & & & & $\mathbf{1}$ \\
\hline Metilergometrin Maleat inj $0,200 \mathrm{mg}-1 \mathrm{ml}$ & & & & & & 1 & & $\mathbf{1}$ \\
\hline Parasetamol $500 \mathrm{mg} \mathrm{tab}$ & 1 & & & & & & & $\mathbf{1}$ \\
\hline Tablet Tambah Darah & & & & 1 & & & & $\mathbf{1}$ \\
\hline Jumlah & 4 & 13 & $\mathbf{1}$ & 11 & 36 & 6 & 1 & 72 \\
\hline Persentase & $5,6 \%$ & $18,1 \%$ & $1,4 \%$ & $15,3 \%$ & $50,0 \%$ & $8,3 \%$ & $1,4 \%$ & $100,0 \%$ \\
\hline
\end{tabular}

Tabel IV. Data Kompilasi Ketersediaan Obat Indikator di DKK di Jawa Tengah Tahun 2015

\begin{tabular}{lcc}
\hline Data Ketersediaan Obat & Nilai & Proporsi \\
\hline Jumlah obat & 665 & \\
Jumlah obat yang tidak ada data. & 8 & $1,2 \%$ \\
Jumlah obat yang tidk ada stol dan pemakainan obat & 59 & $8,9 \%$ \\
Jumlah data obat yang tidak dapat diolah & 67 & $10,1 \%$ \\
Jumlah data yang dapat diolah & 598 & $89,9 \%$ \\
Jumlah obat dengan status tingkat ketersediaan aman & 351 & $58,7 \%$ \\
Jumlah obat dengan tatus tingkat ketersediaan kurang & 247 & $41,3 \%$ \\
\hline
\end{tabular}

Pelaksanaan e-purchasing obat oleh semua DKK di Jawa Tengah tahun 2015, realisasi, hambatan dan tindak lanjutnya ditinjau dari 3 aspek yaitu organisasi DKK, jenis dan jumlah obat (Tabel I).

Hampir semua (97,1\%) DKK melaksanakan e-purchasing pada semua jenis obat indikator yang berjumlah $45,3 \%$ dari jumlah total obat indikator. Realisasi epurchasingsesuai rencana terjadi pada 14,7\% DKK, 26,3\% jenis obat dan 76,1\% jumlah obat. Realisasi e-purchasin gtidak sesuai rencana terjadi pada $85,3 \% \mathrm{DKK}, 73,7 \%$ jenis obat dan $23,9 \%$ jumlah obat.
Hal yang dilakukan oleh DKK yang tidak mengalami hambatan e-purchasing adalah melakukan komunikasi terlebih dahulu kepada IF penyedia sebelum DKK yang tidak mengalami hambatan e-purchasing dilaksanakan. Mereka menyampaikan informasi rencana pengadaan kepada IF penyedia di awal tahun anggaran. IF penyedia menyiapkan barang, setelah barang tersedia IF penyedia akan memberi informasi balik kepada DKK, selanjutnya DKK melakukan e-purchasing obat. Hal ini selaras dengan yang disampaikan oleh Narasimhan dan Kim (2002), dalam rangka mencapai integrasi di perusahaan (integrasi 


\section{Tabel V. Kebijakan dan Langkah DKK dalam Menjamin Ketersediaan Obat dan Status Ketersediaan Obat Indikator di DKK se Jawa Tengah Tahun 2015}

\begin{tabular}{|c|c|c|c|c|c|c|c|c|c|c|c|c|}
\hline \multirow{3}{*}{ Nama Obat } & \multicolumn{12}{|c|}{ Status ketersediaan obat } \\
\hline & \multicolumn{3}{|c|}{$\begin{array}{c}\text { Realisasi F-Purchasing } \\
\text { sesuairencama }\end{array}$} & \multicolumn{3}{|c|}{$\begin{array}{c}\text { Realisasi E-Purchasing tidak } \\
\text { sesuairencana-ditindak } \\
\text { lanjuti }\end{array}$} & \multicolumn{3}{|c|}{$\begin{array}{c}\text { RealisasiE-Purchasing tilak } \\
\text { sesuai rencana- tidak } \\
\text { ditindak lanjuti }\end{array}$} & \multicolumn{3}{|c|}{$\begin{array}{l}\text { Tidak dilakuksan E- } \\
\text { Purchasing }\end{array}$} \\
\hline & Kurang & Aman & $\%$ Aman & Kurang & Aman & $\%$ Aman & Kurang & Aman & $\%$ Aman & Kurang & Aman & 9 Aman \\
\hline A.tbend $a z o t ~ t a b$ & 1 & 5 & $83 \%$ & & & & & & & 14 & 11 & $44 \%$ \\
\hline Amoxicillin $500 \mathrm{mg}$ tab & 3 & 8 & $73 \%$ & 6 & 4 & $40 \%$ & 7 & 4 & $36 \%$ & 1 & 2 & $67 \%$ \\
\hline Anoxicillin syrup $125 \mathrm{mg} / 5 \mathrm{ml}$ & 13 & 12 & $48 \%$ & & & & 1 & 1 & $50 \%$ & 5 & 3 & $38 \%$ \\
\hline Amoxicillin syrup $250 \mathrm{mg} / 5 \mathrm{ml}$ & 0 & 7 & $100 \%$ & & & & & & & 4 & 3 & $43 \%$ \\
\hline Delszmeason ab & 9 & 11 & $55 \%$ & 2 & 2 & $50 \%$ & 3 & 0 & $0 \%$ & 7 & 1 & $13 \%$ \\
\hline Dizzepam irjeksi $5 \mathrm{mg} \mathrm{mL}$ & 0 & 5 & $100 \%$ & & & & 0 & 1 & $100 \%$ & 6 & 16 & $73 \%$ \\
\hline Epinefin (Adrernlin) irjeksi $0,1 \%$ & 4 & 9 & $69 \%$ & 1 & 1 & $50 \%$ & 0 & 1 & $100 \%$ & 9 & 10 & $53 \%$ \\
\hline Fitomenadion $(V$ itamin $\mathrm{K}$ ) irjeksi & 3 & 9 & $75 \%$ & 1 & 1 & $50 \%$ & & & & 11 & 10 & $48 \%$ \\
\hline Furosemid tablet $40 \mathrm{mg}$ & 2 & 4 & $67 \%$ & 0 & 2 & $100 \%$ & 8 & 3 & $27 \%$ & 8 & 7 & $47 \%$ \\
\hline Garam oralit & 1 & 5 & $83 \%$ & & & & 0 & 1 & $100 \%$ & 6 & 21 & $78 \%$ \\
\hline Glibenklamid & 3 & 3 & $50 \%$ & 0 & 2 & $100 \%$ & 8 & 5 & $38 \%$ & 4 & 8 & $67 \%$ \\
\hline Kaptopril tab $12,5 \mathrm{mg}$ & 7 & 5 & $42 \%$ & & & & 1 & 0 & $0 \%$ & 4 & 7 & $64 \%$ \\
\hline Kaptopril tab $25 \mathrm{mg}$ & 6 & 15 & $71 \%$ & & & & & & & 5 & 8 & $62 \%$ \\
\hline Magnesimm Sultat injelsi $20 \%$ & 0 & 7 & $100 \%$ & & & & & & & 8 & 12 & $60 \%$ \\
\hline Meilergometrin Maleat inj $0,200 \mathrm{mg}-1 \mathrm{mi}$ & 5 & 9 & $64 \%$ & & & & 1 & 0 & $0 \%$ & 10 & 7 & $41 \%$ \\
\hline Obat Anti Tuberculosis dew 232 & 1 & 5 & $83 \%$ & & & & & & & 7 & 19 & $73 \%$ \\
\hline Oksitosin injeksi & 4 & 12 & $75 \%$ & 0 & 2 & $100 \%$ & 0 & 1 & $100 \%$ & 8 & 6 & $43 \%$ \\
\hline Paraseamol $500 \mathrm{mg}$ tab & 8 & 22 & $73 \%$ & 0 & 1 & $100 \%$ & & & & 1 & 3 & $75 \%$ \\
\hline Tablet Tambah Darah & 2 & 4 & $67 \%$ & & & & 1 & 0 & $0 \%$ & 17 & 8 & $32 \%$ \\
\hline Jumbh & 72 & 157 & $1379 \%$ & 10 & 15 & $590 \%$ & 30 & 17 & $552 \%$ & 135 & 162 & $1017 \%$ \\
\hline 96 Jumlah obat dengan status aman & & & $69 \%$ & & & $60 \%$ & & & $36 \%$ & & & $55 \%$ \\
\hline Jumbh data & 19 & 19 & 19 & 8 & 8 & 8 & 12 & 12 & 12 & 19 & 19 & 19 \\
\hline Nilairata rata & 3,79 & 8,26 & $73 \%$ & 1,25 & 1,88 & $\mathbf{7 4} \%$ & 2,50 & 1,42 & $46 \%$ & 7,11 & 8,53 & 5496 \\
\hline
\end{tabular}

eksternal), perusahaan harus menyadari pentingnya pemasok sebagai bagian integral dari rantai pasokan dan terlibat dalam upaya kolaboratif dengan mereka. Rantai pasokan memainkan peran penting dalam menciptakan keunggulan kompetitif untuk organisasi. Keberhasilan organisasi terkait dengan pengelolaan rantai pasokan dapat dicapai dengan menggunakan sistem informasi manajemen yang tepat. Meskipun prinsip rantai pasokan obat mirip dengan produk lain, ada isu yang sangat spesifik yang membuat obat berbeda (Yousefia dan Alibabaeib, 2015).

Menurut Pratiwi (2011), ketidaksesuaian perencanaan dan pengadaan obat tidak selalu dipengaruhi oleh keterbatasan dana, tetapi karena keterlambatan pengiriman dan obat tidak terpenuhi oleh pemasok. Dwiaji et al, (2016) menyampaikan pada pengadaan obat secara e-purchasing berdasarkan e-catalogue, kesenjangan antara rencana kebutuhan obat (RKO) nasional dengan pemesanan oleh satuan kerja (satker) atau fasilitas kesehatan (faskes) berakar pada penetapan RKO dan harga perkiraan sendiri, serta penayangan e-catalogue yang tidak memberikan cukup waktu bagi IF pemenang e-catalogue untuk mempersiapkan obat dalam jumlah yang sesuai dengan komitmen pada saat dibutuhkan oleh satker/faskes.

Realisasi e-purchasing tidak sesuai rencana menunjukkan adanya hambatan pada proses pelaksanaan e-purchasing. Pada Tabel II tersaji Kodifikasi jenis hambatan pelaksanaan $e-$ purchasing obat yang dirangkum dari Kementerian Kesehatan RI (2016) dan pengembangan dari hasil penemuan di lapangan selama penelitian.

Identifikasi hambatan pelaksanaan $e$ purchasing (Tabel III). Hasil penelitian (Tabel III) menunjukan bahwa semua hambatan yang terjadi adalah hambatan eksternal, hambatan utama pada sistem suplai dari IF penyedia pemenang harga e-catalogue obat. Hambatan terbanyak sejumlah $50 \%$ adalah E9 yang artinya IF penyedia menyetujui sebagian pesanan karena stok terbatas atau kendala kapasitas produksi, disusul dengan E4 yaitu penolakan 
Tabel VI. Jumlah DKK yang Mengalami Hambatan E-Purchasing tetapi Tidak Ditindaklanjuti dengan Non E-Purchasing dan Status Ketersediaan Obatnya

\begin{tabular}{|c|c|c|c|c|c|}
\hline \multirow{2}{*}{ Nama Obat } & \multirow{2}{*}{$\begin{array}{c}\text { Jumlah DKK } \\
\text { Mengalami } \\
\text { Hambatan }\end{array}$} & \multicolumn{2}{|c|}{ Status Ketersediaan Obat } & \multicolumn{2}{|c|}{ Persentase } \\
\hline & & Kurang & Aman & Kurang & Aman \\
\hline Glibenklamid & 13 & 8 & 5 & $62 \%$ & $38 \%$ \\
\hline Amoxicillin $500 \mathrm{mg}$ tab & 11 & 7 & 4 & $64 \%$ & $36 \%$ \\
\hline Furosemid tablet $40 \mathrm{mg}$ & 11 & 8 & 3 & $73 \%$ & $27 \%$ \\
\hline Deksametason tab & 3 & 3 & 0 & $100 \%$ & $0 \%$ \\
\hline Amoxicillin syrup $125 \mathrm{mg} / 5 \mathrm{ml}$ & 2 & 1 & 1 & $50 \%$ & $50 \%$ \\
\hline Diazepam injeksi $5 \mathrm{mg} / \mathrm{mL}$ & 1 & 0 & 1 & $0 \%$ & $100 \%$ \\
\hline Epinefrin (Adrenalin) injeksi $0,1 \%$ & 1 & 0 & 1 & $0 \%$ & $100 \%$ \\
\hline Garam oralit & 1 & 0 & 1 & $0 \%$ & $100 \%$ \\
\hline Kaptopril tab $12,5 \mathrm{mg}$ & 1 & 1 & 0 & $100 \%$ & $0 \%$ \\
\hline Metilergometrin Maleat inj $0,200 \mathrm{mg}-1 \mathrm{ml}$ & 1 & 1 & 0 & $100 \%$ & $0 \%$ \\
\hline Oksitosin injeksi & 1 & 0 & 1 & $0 \%$ & $100 \%$ \\
\hline Tablet Tambah Darah & 1 & 1 & 0 & $100 \%$ & $0 \%$ \\
\hline Jumlah & 47 & 30 & 17 & $64 \%$ & $36 \%$ \\
\hline
\end{tabular}

Tabel VII. Potensi Penghematan Biaya Obat

\begin{tabular}{|c|c|c|c|c|c|c|c|}
\hline \multirow{2}{*}{ Nama Obat } & \multirow{2}{*}{ Satuan } & \multirow{2}{*}{$\begin{array}{c}\text { Harga } \\
\text { Satuan E- } \\
\text { Catalogue }\end{array}$} & \multirow{2}{*}{$\begin{array}{l}\text { Harga Satuan } \\
\text { rata rata Non E- } \\
\text { Purchasing }\end{array}$} & \multicolumn{3}{|c|}{ Tindak Lanjut Non E-Purchasing } & \multirow{2}{*}{ Selisih B iaya } \\
\hline & & & & Jumlah & $\begin{array}{l}\text { Nilai Non E- } \\
\text { Purchasing }\end{array}$ & $\begin{array}{l}\text { Nilai Jika E- } \\
\text { Purchasing }\end{array}$ & \\
\hline Amoxicillin $500 \mathrm{mg}$ tab & tablet & 272 & 341 & 8.950 .800 & 3.051 .948 .150 & 2.434 .617 .600 & 617.330 .550 \\
\hline Delsametason tab & tablet & 68 & 43 & 2.502 .300 & 107.612 .000 & 168.905250 & $\begin{array}{l}-61.293 .250 \text { Kemasan kaleng 1000, harga } \\
\text { satuan lebih murah }\end{array}$ \\
\hline Epinefin (Adrenalin) irjeksi 0,1\% & ampul & 8.100 & 3.309 & 660 & 2.184 .000 & 5.346 .000 & $\begin{array}{l}\text { Lelang sederhana, harga } \\
-3.162 .000 \text { hmsum, harga satuan lebih } \\
\text { murah }\end{array}$ \\
\hline Fitomena dion $(\mathrm{V}$ itamin $\mathrm{K})$ injeksi & ampul & 3.417 & 8.250 & 1.050 & 8.662 .500 & 3.587 .850 & 5.074 .650 \\
\hline Furosemid tablet $40 \mathrm{mg}$ & tablet & 85 & 90 & 62.400 & 5.584 .800 & 5.304 .000 & 280.800 \\
\hline Glibenklamid & tablet & 56 & 95 & 110.000 & 10.450 .000 & 6.160 .000 & 4.290 .000 \\
\hline Magnesium Sulfat injeksi $20 \%$ & botol & 2800 & 6.600 & 450 & 2.970 .000 & 1.260 .000 & 1.710 .000 Harga belum tercantum pa da \\
\hline Oksitosin injeksi & ampol & 2.200 & 5.810 & 18.400 & 106.898 .000 & 40.480 .000 & 66.418 .000 \\
\hline Parase tamol $500 \mathrm{mg}$ tab & tablet & 89 & 77 & 50.000 & 3.850 .000 & 4.450 .000 & $-600.000 \begin{array}{l}\text { Kemasan kaleng } 1000 \text {, harga } \\
\text { satuan le bih murah }\end{array}$ \\
\hline JUMLAH & & & & & 3.300 .159 .450 & 2.670 .110 .700 & 630.048 .750 \\
\hline PERSENTASE & & & & & & & $19,1 \%$ \\
\hline
\end{tabular}

pemesanan oleh IF penyedia karena stok tidak tersedia $18,1 \%$ dan yang ketiga adalah E8 yang berarti IF penyedia telah menyetujui pemesanan tetapi obat hanya terkirim sebagian sejumlah 15,3\%. Pada penelitian yang dilakukan oleh Matunga et al. (2013) menunjukkan bahwa hambatan terbesar yang dihadapi pengguna $e$ - procurement adalah keterlambatan suplai, pelayanan, dan pekerjaan serta inflasi harga barang, pelayanan dan pekerjaan.

Kendala realisasi terjadi pada jenis obat yang hampir sama di tiap DKK. Empat besar obat yang mengalami kendala adalah amoksisilin tablet $500 \mathrm{mg}$, glibenklamid tablet, 
furosemide tablet dan deksametason tablet. Jenis obat yang mengalami kendala realisasi paling banyak adalah amoksisilin tablet $500 \mathrm{mg}$. Terjadi 21 hambatan pada 32 (65,6\%) DKK yang melaksanakan e-purchasing amoksisilin tablet. Amoksisilin tablet $500 \mathrm{mg}$ adalah jenis obat yang diadakan oleh hampir semua dinas, dalam kuantitas yang terbanyak dan mengambil porsi anggaran yang terbanyak pula.

Harga obat dapat dimungkinkan menjadi penyebab hambatan suplai obat. Dalam penentuan standar harga e-catalogue, telah mempertimbangkan akses obat untuk semua wilayah dengan tetap memberikan iklim yang kondusif kepada industri farmasi untuk tumbuh dan berkembang. Standar harga ditentukan berdasarkan regional wilayah. Regional I : 100\%, regional II : $100 \%+5 \%$, regional III: $100 \%+10 \%$, dan regioanl IV: $100 \%+15 \%$. Harga sudah termasuk biaya distribusi sampai ke Kabupaten/Kota (Muhaemin, 2015). Dalam proses lelang dan negosiasi e-catalogue obat, pemenang lelang hanya satu yaitu industri farmasi yang memberikan penawaran harga yang terendah (Dwiaji et al., 2016). Harga obat generik yang tidak realistis dan terlalu rendah berdampak pada menurunnya ketersediaan obat generik di pasar dan menghilang dari pasar (Sanusi dkk, 2015). Dari sudut pandang industri farmasi, setengah dari total risiko dalam rantai pasokan farmasi menjadi risiko internal industri farmasi yang dapat diperbaiki oleh perusahaan. Risiko yang terjadi memaksa perusahaan untuk fokus pada manajemen keuangan dan pasokan sehingga kurang memperhatikan manajemen mutu (Jaberidoost et al., 2015)

Dampak hambatan pelaksanaan $e$ purchasing berpengaruh terhadap ketersediaan obat. Data ketersediaan obat diambil dari IFK. Pada Tabel IV tergambar kondisi ketersediaan obat indikator di DKK di Jawa Tengah tahun 2015

Dari total 665 data ketersediaan obat indikator yang dihimpun, terdapat $67(10,1 \%)$ data yang tidak dapat diolah, karena sejumlah 8 obat yang tidak ada di IFK, dan 59 obat tidak ada data stok dan pemakaian. Data yang dapat diolah untuk mengetahui tingkat ketersediaan dan ketersediaan obat adalah 598 (89,9\%). Dari 598 data yang bisa diolah, diperoleh hasil bahwa terdapat status tingkat ketersediaan aman sebanyak 351 (58,7 \%), dan status ketersediaan kurang berjumlah 247 (41,3\%)

Hambatan yang terjadi pada pelaksanaan e-purchasing obat yang realisasinya berbeda dengan rencana, memunculkan upaya lain yang harus ditempuh oleh DKK dalam rangka memenuhi ketersediaan obat untuk pelayanan kesehatan dasar di puskesmas dan kebutuhan obat program kesehatan. DKK dapat melakukan berbagai upaya dalam rangka memenuhi ketersediaan obat yang dibutuhkan. Menurut Breen (2008) manajemen farmasi yang efektif di sarana pelayanan kesehatan sangat penting untuk kesejahteraan pasien sehingga risiko harus diidentifikasi dan dikendalikan. Risiko dalam rantai pasokan farmasi berhubungan dengan diskontinuitas produk, kekurangan produk, kinerja yang buruk, keselamatan pasien, kesalahan pengeluaran, dan kesalahan teknologi. Semua risiko mengakibatkan gangguan sistem. Salah satu upaya yang dilakukan oleh DKK adalah melakukan pengadaan obat dengan metode lain yang sah menurut peraturan pengadaan barang/jasa pemerintah selain e-purchasing yang disebut non e-purchasing obat.

Untuk mengetahui kebijakan dan langkah langkah yang dilakukan oleh DKK dalam rangka menjamin ketersediaan obat dan status ketersediaan obat indikator di DKK se Jawa Tengah tahun 2015 dapat dilihat pada Tabel V.

Pada Tabel $\mathrm{V}$ memberikan informasi bahwa jumlah obat yang dalam pelaksanaan $e$ purchasing berjalan lancar mempunyai status ketersediaan aman sebesar 69\%, dengan nilai rata rata $73 \%$. Jumlah obat yang dalam pelaksanaan e-purchasing tidak berjalan lancar dan ditindaklanjuti dengan pengadaan secara non e-purchasing mempunyai status ketersediaan aman sebesar $60 \%$, dengan nilai rata rata $74 \%$. Jumlah obat yang dalam pelaksanaan $e$ purchasing tidak berjalan lancar dan tidak ditindak lanjuti dengan pengadaan secara non $e^{-}$ purchasing mempunyai status ketersediaan aman sebesar $36 \%$, dengan nilai rata rata $46 \%$. Jumlah obat yang tidak diadakan secara $e$ - 
purchasing mempunyai status ketersediaan aman sebesar $55 \%$, dengan nilai rata rata $54 \%$.

Berdasarkan informasi pada Tabel V dapat dikatakan bahwa DKK di Jawa Tengah mempunyai komitmen dalam menjamin ketersediaan obat publik di wilayahnya. Status ketersediaan aman yang kurang dari 50\% hanya terjadi pada obat yang dalam pelaksanaan $e$ purchasing tidak berjalan lancar dan tidak ditindak lanjuti dengan pengadaan secara non epurchasing. Obat yang tidak diadakan secara $e^{-}$ purchasingDKK mempunyai status tingkat ketersediaan aman lebih dari 50\%, hal ini karena sisa persediaan di akhir tahun anggaran yang lalu masih cukup atau DKK melakukan upaya lain dengan mendapatkan dari provinsi atau pihak lain.

Untuk mengetahui dampak hambatan $e$ purchasing pada ketersediaan obat, dilakukan penelusuran status ketersediaan obat pada obat yang mengalami hambatan e-purchasing tetapi tidak ditindak lanjuti dengan pengadaan secara non e-purchasing. Jumlah hambatan yang dialami oleh DKK pada setiap jenis obat dan status ketersediaan obatnya dapat dapat dilihat pada Tabel VI.

Pada Tabel VI tersaji data bahwa semakin besar jumlah hambatan semakin besar nilai ketersediaan obat yang kurang. Hasil menunjukkan bahwa pada total 47 hambatan menyebabkan status ketersediaan kosong sebanyak $64 \%$ dan masih ada $36 \%$ yang mempunyai status ketersediaan yang aman.

Hal ini sesuai dengan hasil penelitian sebelumnya oleh Sutriatmoko (2015) bahwa ada pengaruh signifikan dan positif antara kinerja $e$ purchasing obat terhadap efisiensi pengadaan obat. Kinerja e-purchasing dipengaruhi secara signifikan dan positif oleh manajemen dan kontrol data, kualitas hasil dan produk, serta hubungan dengan mitra kerja.

Pada penelitian ini, hambatan terbesar pada pelaksanaan e-purchasing obat adalan hambatan suplai obat dari IF penyedia. Selaras dengan yang disampaikan oleh Matunga et al. (2013) bahwa hambatan terbesar yang dihadapi pengguna e-procurement adalah keterlambatan suplai. Menurut Yousefia dan Alibabaeib (2015) rantai pasokan berperan penting dalam menciptakan keunggulan kompetitif organisasi. Keberhasilan organisasi dalampengelolaan rantai pasokan dapat dicapai dengan menggunakan sistem informasi manajemen yang tepat.

Penggunaan e-procurement diyakini dapat menekan biaya obat (Dwiaji dkk, 2016). Metode pengadaan obat secara e-purchasing bila berjalan lancar tanpa hambatan akan sangat efisien dan mampu menghemat biaya obat. Potensi penghematan biaya obat pada hasil penelitian ini dapat dilihat pada Tabel VII.

Pada Tabel VII tersaji data harga perolehan obat yang dilakukan secara non epurchasing dan dibandingkan dengan harga perolehan harga yang tercantum pada ecatalogue obat. Pada 12 item obat yang diadakan secara non e-purchasing, nilai perolehnya mencapai Rp 3.300.159.450,-. Bila dikonversikan kedalam harga satuan e-catalogue diperoleh nilai sebesar Rp. 2.670.110.700,- Nilai selisih yang diperoleh yang juga menujukkan potensi penghematan sebesar Rp. 630.048.750,- atau $19,1 \%$ dari nilai perolehan secara non epurchasing. Sesuai dengan penelitian yang dilakukan oleh Ketikidis et al (2010) bahwa biaya penyediaan obat pada fasilitas kesehatan melalui sistem e-procurement terbukti lebih efisien. Ada peningkatan efisiensi, kecepatan dan kemudahan cara pemesanan. Akhirnya ada potensi penghematan biaya yang berdampak pada kenaikan penghasilan. Menurut Talluri et al (2006) keuntungan dari sistem e-procurement meliputi (1) koordinasi yang lebih baik dengan pemasok,(2) transaksi lebih cepat, fleksibilitas yang lebih tinggi, (4) integrasi pemasok yang lebih baik, dan (5) biaya yang lebih rendah

\section{KESIMPULAN}

Pada tahun 2015, terdapat 45,3\% obat indikator diadakan melalui mekanisme $e$ purchasing oleh 97,1\% Dinas Kesehatan Kabupaten/Kota di Jawa Tengah. Realisasi obat yang tidak sesuai rencana ditemukan sebesar 23,9\%. Realisasi obat yang tidak sesuai rencana mengindikasikan adanya hambatan pelaksanaan e-purchasing. Terjadi hambatan dalam pelaksanaan e-purchasing obat. Hambatan 
terbesar adalah ketidak mampuan suplai oleh Industri Farmasi penyedia. Hambatan berdampak pada pengurangan ketersediaan obat sebesar $64 \%$ dan mengurangi efisiensi biaya obat. Pelaksanaan e-purchasing yang berjalan lancar akan menyumbangkan potensi penghematan biaya obat sebesar $19,1 \%$.

\section{UCAPAN TERIMA KASIH}

Penulis menyampaikan terima kasih kepada Badan PPSDM Kesehatan yang telah membiayai penelitian ini dan para pihak yang membantu pengambilan dan analisis data penelitian.

\section{DAFTAR PUSTAKA}

Bottani E. and Rizzi A., 2005, A Fuzzy Multiattribute Framework for Supplier Selection in an e-Procurement Environment, International Journal of Logistics: Research and Applications, 8(3): 249-266.

Breen, L., 2008, A Preliminary Examination of Risk in the Pharmaceutical Supply Chain (PSC) in the National Health Service (NHS) (UK), Journal Services Science \& Management, 1: 193-199

Dwiaji, A., Sarnianto, P., Thabrany, H., et.al, 2016, Evaluasi Pengadaan Obat Publik pada JKN Berdasarkan Data e-Catalogue Tahun 2014-2015, Jurnal Ekonomi Kesehatan Indonesia, 1(1) : 39-53

Eei, K.S., Husain, W., Mustaffa, N., 2012, Survey on Benefit and Barriers of E-Procurement : Malaysian SMEs Perspective, International Journal on Advantaced Science Engineering Information Technology, 2(6): 14-19

Gunasekaran, A., Ngai, E.W.T., 2008, Adoption of E-Procurement in Hong Kong: An Empirical Research, International Journal of Production Economics, 113: 159-175.

Iswahyudi, 2007, Proses Pengadaan Obat di Dinas Kesehatan Kabupaten Bereu, Tesis, Universitas Gadjah Mada, Yogyakarta.

Jaberidoost, M., dkk, 2015, Pharmaceutical supply chain risk assessment in Iran using analytic hierarchy process (AHP) and simple additive weighting (SAW) methods, Journal of Pharmaceutical Policy and Practice, 8:9

Kementerian Kesehatan RI, 2014,Peraturan Menteri Kesehatan Republik Indonesia Nomor 63 Tahun 2014 Tentang Pengadaan Obat Berdasarkan Katalog Elektronik (ECatalogue), Kementerian Kesehatan RI, Jakarta.

Kementerian Kesehatan RI, 2016, Paparan Direktur Tatakelola Obat Publik dan Perbekalan Kesehatan, dalam Rapat Koordinasi Nasional Program Kefarmasian dan Alat kesehatan Kemenkes RI, Palembang

Ketikidis, P.H., Kontogeorgis, A., Stalidis, G., et.al., 2010, Applying e-Procurement System in the Healthcare: the EPOS paradigm, International Journal of Systems Science41(3):281-299

Matunga, D.A., Nyanamba, S.O., Okibo, W., 2013, The Effect of E-Procurement Practices on Effective Procurement in Public Hospitals: A Case of KISII Level 5 Hospital, American International Journal of Contemporary Reseach, 3(8): 103-111

Muhaemin, E.A., 2015, Drugs Policy Challenger in Emerging Markets Indonesia, Educational Forum International Society For Pharmacoeconomics and Outcomes Research (ISPOR), 18 ${ }^{\text {th }}$, Milan, 9 November 2015

Narasimhan, R., dan Kim, S., 2002, Effect of Supply Chain Integration on the Relationship between Diversification and Performance: Evidence from Japanese and Korean Firms, Journal of Operations Management, 20, 303-323.

Ningsih, A., Fudholi, A., Sumarni, 2016, Hubungan Penerapan Elektronik Katalog terhadap Efisiensi Pengadaan dan Ketersediaan Obat, Jurnal Manajemen dan Pelayanan Farmasi,5 (4) : 233-240.

Pratiwi, F., 2011, Evaluasi Perencanaan dan Pengadaan Obat di Instalasi Farmasi Dinas Kesehatan Kota Semarang, Tesis, Universitas Gadjah Mada, Yogyakarta.

Puspita, G., 2009, Evaluasi Perencanaan dan Pengadaan Obat di Dinas Kesehatan Kabupaten Majalengka Tahun 2006, 2007, 
dan 2008, Tesis, Universitas Gadjah Mada, Yogyakarta.

Sanusi, D., Setijono, J., Soetikno, F., 2015, Peran GP Farmasi Indonesia dalam Pengadaan Obat untuk JKN, disampaikan dalam Dialog Kebijakan Farmasi untuk Penguatan Sistem Kesehatan Nasional dalam Era JKN, Jakarta, 05 Mei 2015

Sigulem, F., dan Zucchi P., 2009, E-procurement in the Brazilian healthcare system: the impact of joint drug purchases by a hospital network, Rev Panam Salud Publica, 26(5) : 429-434.

Sutriatmoko, Satibi, Puspandari, D.A., 2015, Analisis penerapan E-Procurement obat dengan Prosedur E-Purchasing berdasar E-Catalogue di Dinas Kesehatan Kabupaten/Kota di Jawa Tengah, Jurnal Manajemen dan Pelayanan Farmasi,5 (4) : 268-274.
Talluri, A., Chung W. and Narasimhan, R., 2006, An Optimisation Model for Phased Supplier Integration into e-Procurement Systems, IIETransactions, 38, 389-399.

Teo, T.S.H., Lin, S., Lai, K., 2009, Adopters and non-Adopters of e-Procurement in Singapore: An Empirical Study, Omega, 37: 972-987.

Yousefia, N., and Alibabaeib, A., 2015, 'Information Flow in the Pharmaceutical Supply Chain', Iranian Journal of Pharmaceutical Research, 14 (4): 1299-1303.

Winarni, 2006, Perbandingan Efisiensi dan Efektivitas Pengadaan Obat dan Alat Kesehatan dengan Lelang, Penunjukan Langsung dan Kemitraan di Kabupaten Sleman, Tesis, Universitas Gadjah Mada, Yogyakarta. 